University of Texas Rio Grande Valley

ScholarWorks @ UTRGV

Chemistry Faculty Publications and

Presentations

College of Sciences

$12-21-2013$

\title{
Asymmetric Supercapacitors With Dominant Pseudocapacitance Based on Manganese Oxide Nanoflowers in a Neutral Aqueous Electrolyte
}

Qiang Li

The University of Texas Rio Grande Valley

Xing Sun

The University of Texas Rio Grande Valley

Karen Lozano

The University of Texas Rio Grande Valley, karen.lozano@utrgv.edu

Yuanbing Mao

The University of Texas Rio Grande Valley

Follow this and additional works at: https://scholarworks.utrgv.edu/chem_fac

Part of the Chemistry Commons

\section{Recommended Citation}

Li, Q., Sun, X., Lozano, K., \& Mao, Y. (2013). Asymmetric supercapacitors with dominant pseudocapacitance based on manganese oxide nanoflowers in a neutral aqueous electrolyte. RSC Advances, 3(47), 24886-24890. https://doi.org/10.1039/C3RA45140B

This Article is brought to you for free and open access by the College of Sciences at ScholarWorks @ UTRGV. It has been accepted for inclusion in Chemistry Faculty Publications and Presentations by an authorized administrator of ScholarWorks@ UTRGV. For more information, please contact justin.white@utrgv.edu,william.flores01@utrgv.edu. 
Electronic Supplementary Information

\title{
Asymmetric Supercapacitors with Dominant Pseudocapacitance Based on Manganese Oxide Nanoflowers in Neutral Aqueous Electrolyte
}

\author{
Qiang Li, ${ }^{\mathrm{a}, \mathrm{b}}$ Xing Sun, ${ }^{\mathrm{a}}$ Karen Lozano ${ }^{\mathrm{b}}$ and Yuanbing Mao ${ }^{\mathrm{a},{ }^{*}}$ \\ ${ }^{a}$ Department of Chemistry, University of Texas - Pan American, Edinburg, TX 78539 USA \\ ${ }^{b}$ Department of Mechanical Engineering, University of Texas - Pan American, Edinburg, TX \\ 78539 USA
}

*To whom correspondence should be addressed: Phone: +1 956665 2417; Fax: +1 956665 5006; E-mail: maoy@utpa.edu

\section{Experimental Section}

Synthesis of manganese oxide nanoflowers ( $\mathrm{MnO}_{2}-\mathrm{NFS}$ ): In a typical synthesis, $0.8 \mathrm{mmol}$ of $\mathrm{KMnO}_{4}$ was dissolved into $36 \mathrm{~mL}$ of deionized water under vigorous magnetic stirring for 20 min. Then $4.385 \mathrm{~mL}$ of N-Methyl-2-pyrrolidone (NMP) was added into the above solution and the mixture was stirred for another 5 min before kept still at $25-60{ }^{\circ} \mathrm{C}$ for $6-20 \mathrm{~h}$. Subsequently, the brown-black precipitate was collected and repeatedly washed with deionized water and ethanol, and then dried in a vacuum oven overnight.

Functionalization of carbon nanotubes (CNTs): $0.1 \mathrm{~g}$ of pristine MWCNTs (Sigma Aldrich, product No. 636517) were immersed into $150 \mathrm{~mL}$ concentrated nitric acid and refluxed at $70{ }^{\circ} \mathrm{C}$ for $3 \mathrm{~h}$ to remove metal catalyst impurities and yield oxygenated functional groups on the surface. The CNTs were filtered with a $0.45 \mu \mathrm{m}$ PTFE membrane and washed with deionized water until the $\mathrm{pH}$ value of the supernatant was close to 7. The resultant CNTs were redispersed into ethanol for further utilization.

Material characterization: The $\mathrm{MnO}_{2}$-NFs were characterized by field emission scanning electron microscopy (SEM, Carl Zeiss Sigma VP, equipped with scanning transmission electron microscopy (STEM)), energy dispersive X-ray spectroscopy (EDS), transmission electron microscopy (TEM, Zeiss LEO 900), X-ray powder diffraction (XRD, Rigaku Miniflex II with Cu $\mathrm{K} \alpha$ radiation, Raman spectroscopy (Bruker SENTERRA, $785 \mathrm{~nm}$ laser as excitation source), porosimetry analyzer (Micromeritics ASAP 2020 Analyzer, nitrogen adsorption at 77K), and Fourier transform infrared spectroscopy (FTIR, Thermal Nicolet Nexus 470 spectrometer).

Electrochemical measurements: All electrochemical measurements were conducted using a Gamry reference 600 Potentiostat/Galvanostat/ZRA workstation. For three-electrode testing, platinum gauze and $\mathrm{Ag} / \mathrm{AgCl}$ were used as the counter and reference electrodes, respectively. The working electrodes of $\mathrm{MnO}_{2}-\mathrm{NFs}$ or CNTs were fabricated as below: The as-prepared 
$\mathrm{MnO}_{2}$-NFs (70 wt.\%) were evenly mixed and grinded with carbon black (20 wt.\%) and polyvinylidene fluoride (PVDF, $10 \mathrm{wt} . \%$ ) in ethanol and the formed slurry was pasted onto a graphite paper disk (19 $\mathrm{mm}$ in diameter). The CNT electrode was prepared by pasting a mixture of CNTs and PVDF (90:10 in weight ratio) onto graphite fiber paper disk. They were pre-dried in a vacuum oven at $70{ }^{\circ} \mathrm{C}$ overnight. The graphite fiber papers are chosen as current collectors to prevent capacitance fading from delamination issue and an undesirable electrochemical corrosion towards traditional metallic foils. The porous characteristic of them allows heavy depositions of electroactive materials without penalizing the rate capacity of ASCs to deliver sufficient power for practical applications. The specific capacitance in this work is obtained after excluding the slight contribution of graphite fiber paper.

Based on $\mathrm{CV}$ measurements, the charges $(q)$ stored on both electrodes were balanced according to $q=C_{s} \times \Delta V \times m$, where $C_{s}$ is the specific capacitance, $\Delta V$ is the potential window, and $m$ is the mass of active electrode material.

To build our ASCs, the optimal mass ratio between the $\mathrm{MnO}_{2}-\mathrm{NFs}$ and CNTs was calculated to be 0.48 based on the relationship of $q^{+}=q^{-}$with respective $\mathrm{Cs}$ of $\mathrm{MnO}_{2}$-NFs and CNTs as 145.4 and $70.3 \mathrm{~F} \mathrm{~g} \mathrm{~g}^{-1}$, respectively, at $20 \mathrm{mV} \mathrm{s}^{-1}$. The actual loading amount for positive and negative materials on graphite current collector is $0.62 \mathrm{mg}$ and $1.02 \mathrm{mg}$ including the additives, respectively. The $\mathrm{MnO}_{2}-\mathrm{NFs} / \mathrm{CNTs}$ ASCs separated by an electrolyte-cast glassy fiber separator (Millipore Co., $0.45 \mu \mathrm{m}$ pore size, $19 \mathrm{~mm}$ in diameter) were then assembled into a stainless steel split flat cell (MTI Co.) in an Ar-filled glove box. The $2 \mathrm{M} \mathrm{KCl}$ aqueous solution was purged with high purity argon for $30 \mathrm{~min}$ for oxygen removal and used as the electrolyte. Chloride electrolyte was chosen over conventional sulfate electrolytes deliberately to improve the mobility of cations due to the relatively small ionic radius of chloride anions (ionic radii $1.67 \AA$ of $\mathrm{Cl}^{-}$vs $2.30 \AA$ of $\mathrm{SO}_{4}{ }^{2-}$ ) in order to further reduce the kinetic limitations. The $\mathrm{MnO}_{2}-\mathrm{NFs} / / \mathrm{MnO}_{2}-\mathrm{NFs}$ and CNTs//CNTs symmetric supercapacitors were constructed following the same procedure.

The specific capacitance calculated from the CV curves can be derived from:

$$
C_{s}=\frac{\int_{V_{2}}^{V_{1}} i(V) d V}{2 \times\left(V_{2}-V_{1}\right) \times m \times v}
$$

where $C_{s}$ is the specific capacitance from evaluated samples; $V_{1}$ and $V_{2}$ are the starting and ending points of potential window, respectively; $i(V)$ is the instantaneous current as the function of potential; $\mathrm{m}$ is the mass of active electrode materials, and is the total mass of both electrode materials for ACS device and two symmetric devices; and $v$ is the scan rate in $\mathrm{mV} \mathrm{s}^{-1}$. The mass is measured using A\&D HR-202i analytical balance with readability of $0.01 \mathrm{mg}$.

The specific capacitance calculated from the galvanostatic charge/discharge measurements can be derived from:

$$
C_{s}=\frac{I \times t}{\Delta V \times m}
$$


$I$ and $t$ are the discharge current and the discharge time, respectively in the potential range $\Delta V$ excluding the IR drop.

The energy density $E$ at different power density $P$ of the $\mathrm{MnO}_{2}-\mathrm{NFs} / / \mathrm{CNT}$ asymmetric supercapacitor, $\mathrm{MnO}_{2}-\mathrm{NFs} / / \mathrm{MnO}_{2}-\mathrm{NFs}$ and $\mathrm{CNTs} / / \mathrm{CNTs}$ symmetric supercapacitors is calculated from the $\mathrm{CV}$ curves at different scan rates according to the equation below:

$$
E=\frac{C_{s} \times V^{2}}{2}=\frac{500 \times C_{s} \times V^{2}}{3600}(\mathrm{Wh} / \mathrm{kg})
$$

and power density $P$ is calculated following:

$$
P=\frac{E}{t}=\frac{3600 \times E}{t}(\mathrm{~W} / \mathrm{kg})
$$

where $C_{s}$ is the specific capacitance in $\mathrm{F} \mathrm{g}^{-1}$ of devices at a corresponding scan rate; $V$ is the cell potential and $t$ is the discharge time period in seconds from $\mathrm{V}$ to $0 \mathrm{~V}$.

Coulombic efficiency is estimated according to:

$$
\eta=\frac{t_{D}}{t_{C}} \times 100 \%
$$

where $\eta$ is coulombic efficiency, $t_{\mathrm{D}}$ and $t_{\mathrm{C}}$ is the glavanostatic charge and discharge time, respectively.

The $\mathrm{K}^{+}$Faradic intercalation/deintercalation reaction of the as-synthesized $\mathrm{MnO}_{2}-\mathrm{NFs}$ is represented below:

$$
K_{0.26} \mathrm{MnO}_{2}+\delta M^{+}+\delta e^{-} \Leftrightarrow K_{0.26} M_{\delta} \mathrm{MnO}_{2}\left(M^{+}=K^{+} \text {or } \mathrm{H}_{3} \mathrm{O}^{+}\right)
$$

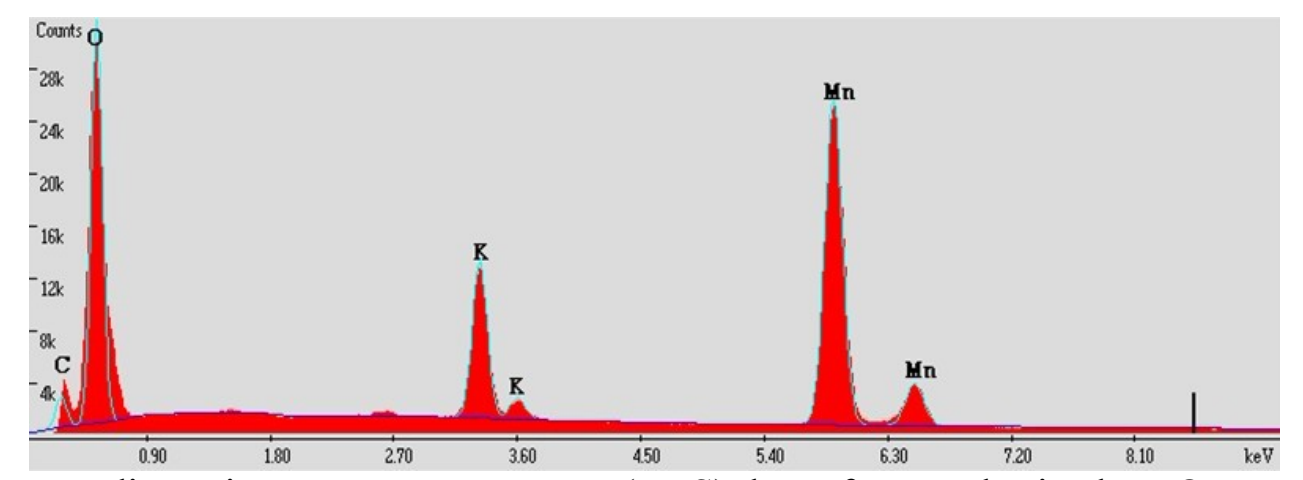

Fig. S1 Energy-dispersive X-ray spectroscopy (EDS) data of as-synthesized $\mathrm{MnO}_{2}-\mathrm{NFs}$. 
In virtue of the strong acidity and oxidizing property of $\mathrm{KMnO}_{4}$, we hypothesize that the pyrrolidone ring-opening reaction of the NMP molecules would yield refined $\mathrm{MnO}_{2}$ nanostructures. In our synthesis, overabundant NMP is used to react with strong oxidizing agent $\mathrm{KMnO}_{4}$ to synthesize homogeneously distributed $\mathrm{MnO}_{2}$ nanostructures at relatively low temperature. The high bond strength of C-N $\left(292 \mathrm{~kJ} \mathrm{~mol}^{-1}\right)$ would give rise to a high reaction activation energy and accordingly brings a significant effect on $\mathrm{MnO}_{2}$ nucleation and growth rates. Infrared spectra (Fig. S2) were recorded to insightfully investigate synthesis process. The resultant precipitation was first deliberately filtrated and rinsed with water to exclude the influence of residual NMP to the effect that the superficial product compounds on $\mathrm{MnO}_{2}$ could be detected by IR spectrum and this sample is denoted as filtrated $\mathrm{MnO}_{2}$ (Fig. S2b).

As shown in Fig. S2, most interesting observation in the IR curve from the filtrated $\mathrm{MnO}_{2}$ is that the $\mathrm{N}-\mathrm{C}_{3}$ stretching vibration bands, located at $1504 \mathrm{~cm}^{-1}$, of $\mathrm{N}-\mathrm{C}=\mathrm{O}$ in the pyrrolidone ring disappears, whereas the $\mathrm{N}-\mathrm{C}_{1}$ at $\sim 1264 \mathrm{~cm}^{-1}$ and $\mathrm{N}-\mathrm{C}_{2}$ bonds at $\sim 1301 \mathrm{~cm}^{-1}$ have similar chemical environments in comparison with IR spectrum of pure NMP. The other great change is an apparent absorption peak at $\sim 1567 \mathrm{~cm}^{-1}$ corresponding to $\mathrm{N}-\mathrm{H}$ bending vibration of amines emerges in filtrated $\mathrm{MnO}_{2}$ specimen. Additionally, the relative intensity difference among the C$\mathrm{H}$ vibrational bands is noticeable, which was regarded as evidence of capping ligands chemisorbing on the $\mathrm{MnO}_{2}$ nanocrystals. Meanwhile, a remarkable broad band centered at 500 $\mathrm{cm}^{-1}$ can be ascribed to the $\mathrm{Mn}-\mathrm{O}$ vibrations in $\mathrm{MnO}_{6}$ octahedra. The results demonstrate that the NMP undergoes the $\mathrm{N}-\mathrm{C}_{3}$ breaking of pyrrolidone rings in the presence of $\mathrm{KMnO}_{4}$ and generate $\mathrm{MnO}_{2}$ in spite of not eliminating the possibility that the partial NMP might be accompanied with their intrinsic hydrolysis in acidic atmosphere. However, whether the hypothetic by-product, namely 4-(Methylamino)butyric acid, is able to continue being oxidized by $\mathrm{KMnO}_{4}$ through the breaking of $\mathrm{C}-\mathrm{N}$ bonds is still under investigation and the likelihood of the occurrence of oxidative azo coupling reaction among the $\mathrm{C}-\mathrm{NH}-\mathrm{C}$ bonds is ruled out due to the absence of acidic catalyst and overabundance of NMP addition. 


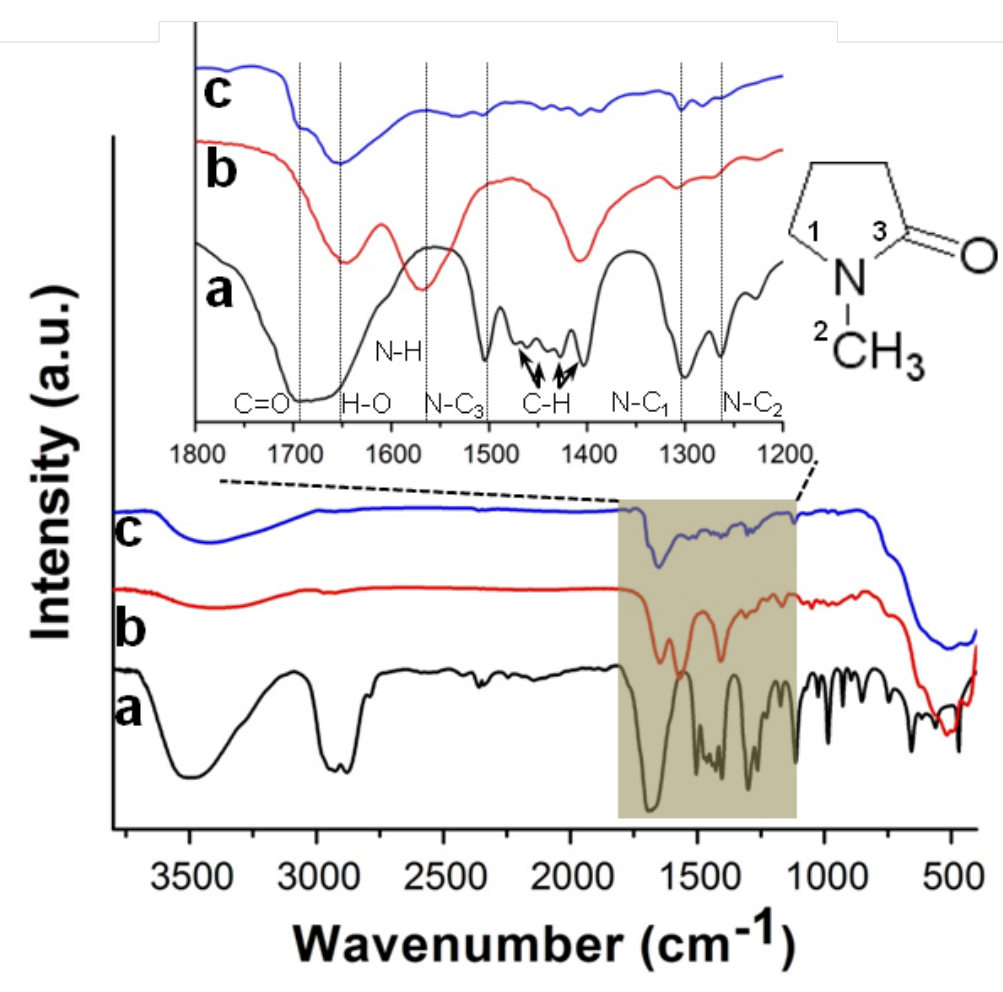

Fig. S2 FTIR spectra of (a) pure NMP, (b) filtrated $\mathrm{MnO}_{2}-\mathrm{NFs}$ after DI water rinse, and (c) thoroughly rinsed $\mathrm{MnO}_{2}$-NFs with DI water and ethanol.

Therefore, the plausible formation mechanism of these monodisperse sub-30 nm $\mathrm{MnO}_{2}-\mathrm{NFs}$ is as follow: N-Methyl-2-pyrrolidone (NMP) reduces $\mathrm{KMnO}_{4}$ to generate $\mathrm{MnO}_{2}$. The initially formed $\mathrm{MnO}_{2}$ nuclei experience a rapid growth and fuse into amorphous aggregations. As the reaction proceeds, an Ostwald ripening mechanism takes over the growth. The ultrathin nanoflakes form according as the lamellar crystal structures of birnessite-type $\mathrm{MnO}_{2}$ and/or anisotropic growth caused by the selective chemisorption of 4-(Methylamino)butyric acid on certain crystal planes, and subsequently self-assemble into flower-like nanostructures. The further growth of these nanoflowers stops after depletion of $\mathrm{KMnO}_{4}$ in the solution. The possible surface capping by 4-(Methylamino)butyric acid and/or its protection networks by hydrogen bonds between its nitrogen donors may prevent $\mathrm{MnO}_{2}-\mathrm{NFs}$ from growing. Comparing to previous studies, the high activation energy for the pyrrolidone ring-opening of NMP is capable of effectively downsizing the formed $\mathrm{MnO}_{2}-\mathrm{NFs}$. 


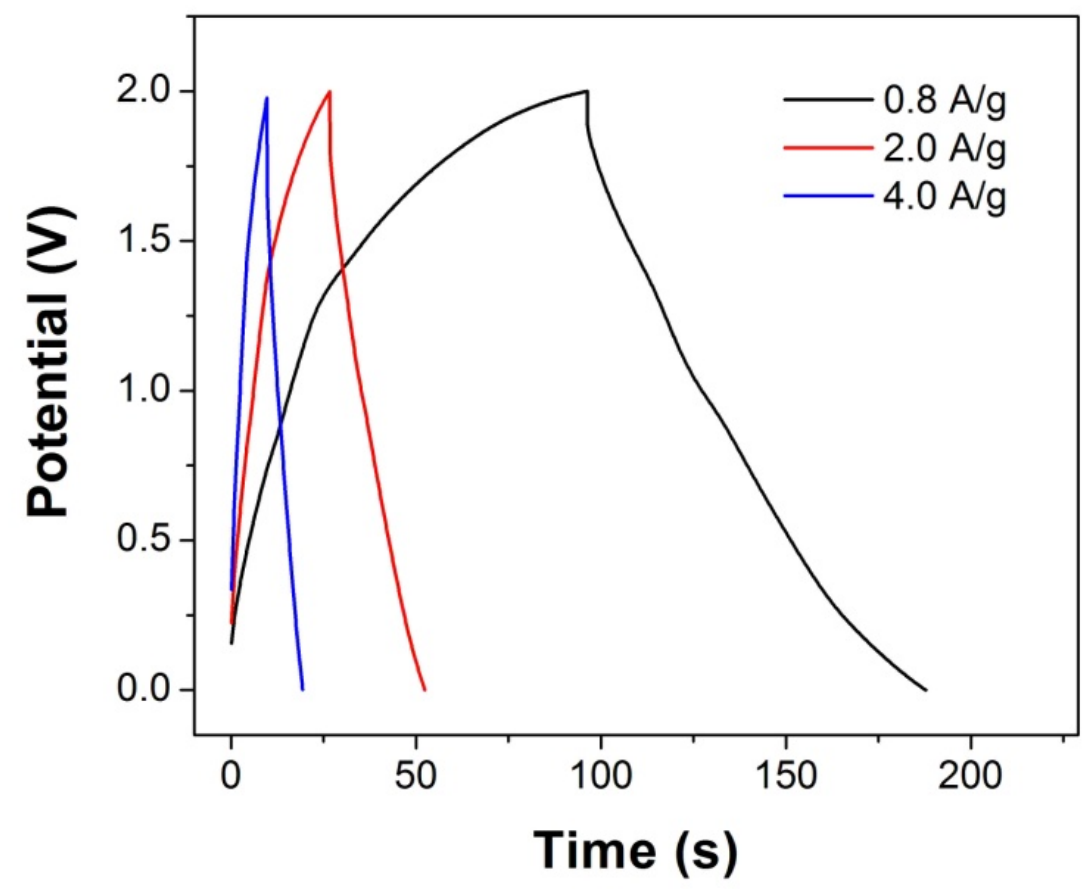

Fig. S3 Galvanostatic charge/discharge curves at different current densities of $0.8,1.0$ and $2.0 \mathrm{~A}$ $\mathrm{g}^{-1}$ of the as-assembled ASCs.

Table S1: Summary of Electrochemical Data of $\mathrm{MnO}_{2}$-based Supercapacitors

\begin{tabular}{|c|c|c|c|c|c|c|c|}
\hline $\begin{array}{l}\text { Cathode } \\
\text { material }\end{array}$ & $\begin{array}{l}\text { Cathode material } \\
\text { morphology/size }\end{array}$ & $\begin{array}{c}\text { Anode } \\
\text { material }\end{array}$ & $\begin{array}{l}\text { Electrolyte } \\
\text { solution }\end{array}$ & $\begin{array}{l}\text { Potential } \\
\text { window } \\
\text { (V) }\end{array}$ & $\begin{array}{c}\text { Maximum } \\
\text { capacitance } \\
(\mathrm{F} / \mathrm{g})\end{array}$ & $\begin{array}{c}\text { Energy density } \\
(\mathrm{Wh} / \mathrm{kg}) \text { at } \mathrm{P} \\
\text { power density } \\
(\mathrm{W} / \mathrm{kg})\end{array}$ & $\begin{array}{c}\text { Capacitance } \\
\text { retention after n } \\
\text { cycles }\end{array}$ \\
\hline $\mathrm{MnO}_{2}{ }^{1}$ & - & $\mathrm{AC}$ & $\mathrm{KCl}$ & 2.0 & 52 & $28.8(\mathrm{P}=500)$ & $(\mathrm{n}=100)$ \\
\hline $\mathrm{MnO}_{2}{ }^{2}$ & $20-500 \mathrm{~nm}$ grains & $\mathrm{AC}$ & $\mathrm{K}_{2} \mathrm{SO}_{4}$ & 1.5 & - & $\sim 7.0(\mathrm{P}=400)$ & $76 \%(\mathrm{n}=23,000)$ \\
\hline $\mathrm{MnO}_{2}{ }^{3}$ & $\sim 200 \mathrm{~nm}$ grains & $\mathrm{AC}$ & $\mathrm{K}_{2} \mathrm{SO}_{4}$ & 2.2 & 31 & $17.3(\mathrm{P}=605)$ & $\sim 87 \%(\mathrm{n}=5,000)$ \\
\hline $\mathrm{MnO}_{2}{ }^{4}$ & - & $\mathrm{AC}$ & $\mathrm{K}_{2} \mathrm{SO}_{4}$ & 2.0 & $21 \pm 2$ & $11.7(-)$ & $\begin{array}{c}87.5 \%(\mathrm{n}= \\
195,000)\end{array}$ \\
\hline$\delta-\mathrm{K}_{0.27} \mathrm{MnO}_{2}{ }^{5}$ & $\begin{array}{c}50-200 \mathrm{~nm} \text { aggregated } \\
\text { particles }\end{array}$ & $\mathrm{AC}$ & $\mathrm{K}_{2} \mathrm{SO}_{4}$ & 1.8 & 57.7 & $25.3(\mathrm{P}=140)$ & $\begin{array}{c}\geq 98 \%(\mathrm{n}= \\
10,000)\end{array}$ \\
\hline $\mathrm{NaMnO}_{2}{ }^{6}$ & $\begin{array}{l}50 \mu \mathrm{m} \text { aggregated } \\
\text { spherical particles }\end{array}$ & $\mathrm{AC}$ & $\mathrm{Na}_{2} \mathrm{SO}_{4}$ & 1.9 & 38.9 & $19.5(\mathrm{P}=130)$ & $\begin{array}{c}\geq 97 \%(\mathrm{n}= \\
10,000)\end{array}$ \\
\hline$\delta-\mathrm{MnO}_{2}{ }^{7}$ & $\begin{array}{l}400-600 \mathrm{~nm} \text { corona } \\
\text { structures }\end{array}$ & $\mathrm{AC}$ & $\mathrm{Na}_{2} \mathrm{SO}_{4}$ & 2.0 & 30.8 & $17.1(\mathrm{P}=100)$ & - \\
\hline$\alpha-\mathrm{MnO}_{2}{ }^{8}$ & $\begin{array}{l}\text { 3D mesoporous } \\
\text { frameworks }\end{array}$ & $\mathrm{AC}$ & $\mathrm{Na}_{2} \mathrm{SO}_{4}$ & 1.8 & 23.1 & $10.4(-)$ & $-(\mathrm{n}=1,200)$ \\
\hline$\varepsilon-\mathrm{MnO}_{2}{ }^{9}$ & $\begin{array}{l}\text { Aligned nanoplates on } \\
\text { nickel foam }\end{array}$ & $\begin{array}{l}\text { Graphene } \\
\text { hydrogel }\end{array}$ & $\mathrm{Na}_{2} \mathrm{SO}_{4}$ & 2.0 & 26.8 & $23.2(\mathrm{P}=1,000)$ & $83.4 \%(\mathrm{n}=5,000)$ \\
\hline$\delta-\mathrm{MnO}_{2}{ }^{10}$ & $\begin{array}{c}\leq 10 \mathrm{~nm} \text { in diameter } \\
\text { nanorods }\end{array}$ & $\mathrm{AC}$ & $\mathrm{K}_{2} \mathrm{SO}_{4}$ & 1.8 & 53.7 & $17(\mathrm{P}=2,000)$ & $\begin{array}{c}\geq 94 \%(\mathrm{n}= \\
23,000)\end{array}$ \\
\hline $\mathrm{MnO}_{2}{ }^{11}$ & $\sim 50 \mathrm{~nm}$ nanoparticles & Graphene & $\mathrm{Na}_{2} \mathrm{SO}_{4}$ & 2.0 & 37 & $25.2(\mathrm{P}=100)$ & $96 \%(\mathrm{n}=500)$ \\
\hline
\end{tabular}




\begin{tabular}{|c|c|c|c|c|c|c|c|}
\hline $\begin{array}{l}\mathrm{K}_{0.15} \mathrm{MnO}_{2} \\
/ \mathrm{PEDOT}^{12}\end{array}$ & Nanosheets & PEDOT & $\mathrm{Na}_{2} \mathrm{SO}_{4}$ & 1.2 & 77.2 & $15.4(-)$ & $87.8 \%(\mathrm{n}=1,000)$ \\
\hline$\underset{\text { mixture }}{\alpha-\mathrm{MnO}_{2} / \mathrm{CNTs}}$ & - & $\mathrm{AC}$ & $\mathrm{KNO}_{3}$ & 2.0 & 140 & $21(-)$ & $88 \%(n=1,000)$ \\
\hline$\underset{\text { mixture }^{14}}{\alpha-\mathrm{MnO}_{2} / \mathrm{CNTs}}$ & - & $\begin{array}{l}\text { PANI/CNTs } \\
\text { composite }\end{array}$ & $\mathrm{KNO}_{3}$ & 1.2 & - & $5.86(-)$ & - \\
\hline$\underset{\text { mixture }^{14}}{\alpha-\mathrm{MnO}_{2} / \mathrm{CNTs}}$ & - & $\begin{array}{l}\mathrm{PPy} / \mathrm{CNTs} \\
\text { composite }\end{array}$ & $\mathrm{H}_{2} \mathrm{SO}_{4}$ & 1.4 & - & $7.37(-)$ & - \\
\hline$\underset{\text { mixture }^{14}}{\alpha-\mathrm{MnO}_{2} / \mathrm{CNTs}}$ & - & $\begin{array}{l}\text { PEDOT } \\
\text { /CNTs }\end{array}$ & $\mathrm{KNO}_{3}$ & 1.8 & - & $13.5(-)$ & $91 \%(\mathrm{n}=500)$ \\
\hline $\begin{array}{l}\alpha-\mathrm{MnO}_{2} \\
\text { /graphene }^{15}\end{array}$ & $\begin{array}{l}10-20 \mathrm{~nm} \text { in diameter } \\
\text { nanowires on graphene }\end{array}$ & Graphene & $\mathrm{Na}_{2} \mathrm{SO}_{4}$ & 2.0 & 31 & $30.4(\mathrm{P}=\sim 100)$ & $\sim 79 \%(\mathrm{n}=1,000)$ \\
\hline $\mathrm{MnO}_{2} / \mathrm{GHCS}^{16}$ & $\begin{array}{l}20-50 \mathrm{~nm} \text { in length } \\
\text { nanofibers on GHCS }\end{array}$ & GHCS & $\mathrm{Na}_{2} \mathrm{SO}_{4}$ & 2.0 & 24.5 & $22.1(\mathrm{P}=7,000)$ & $99 \%(\mathrm{n}=1,000)$ \\
\hline $\mathrm{MnO}_{2} /$ graphene $^{17}$ & Nanorods on graphene & Graphene/Ag & $\mathrm{Na}_{2} \mathrm{SO}_{4}$ & 1.8 & 112.8 & $50.8(\mathrm{P}=101.5)$ & - \\
\hline $\mathrm{MnO}_{2} /$ graphene $^{18}$ & $\begin{array}{l}\text { Nanoparticles on } \\
\text { graphene }\end{array}$ & $\mathrm{ACN}$ & $\mathrm{Na}_{2} \mathrm{SO}_{4}$ & 1.8 & 113.5 & $51.1(\mathrm{P}=198)$ & $97 \%(n=1,000)$ \\
\hline $\begin{array}{l}\mathrm{K}_{0.26} \mathrm{MnO}_{2} \\
\text { (this work) }\end{array}$ & $\begin{array}{c}\sim 25 \text { nm nanoflake } \\
\text { assemblies }\end{array}$ & CNTs & $\mathrm{KCl}$ & 2.0 & 81.7 & $45.5(\mathrm{P}=163.5)$ & $\begin{array}{l}\text { No definite loss } \\
(\mathrm{n}=20,000)\end{array}$ \\
\hline
\end{tabular}

Abbreviations: activated carbon (AC), polyaniline (PANI), polypyrrole (Ppy), poly(3,4ethylenedioxythiophene) (PEDOT), stainless steel (SS), carbon nanotubes (CNTs), graphitic hollow carbon spheres (GHCS). To identify easily, the monocomponent $\mathrm{MnO}_{2}$-based ASCs are red-labeled and the hybrid $\mathrm{MnO}_{2}$-based ASCs are blue-labeled.

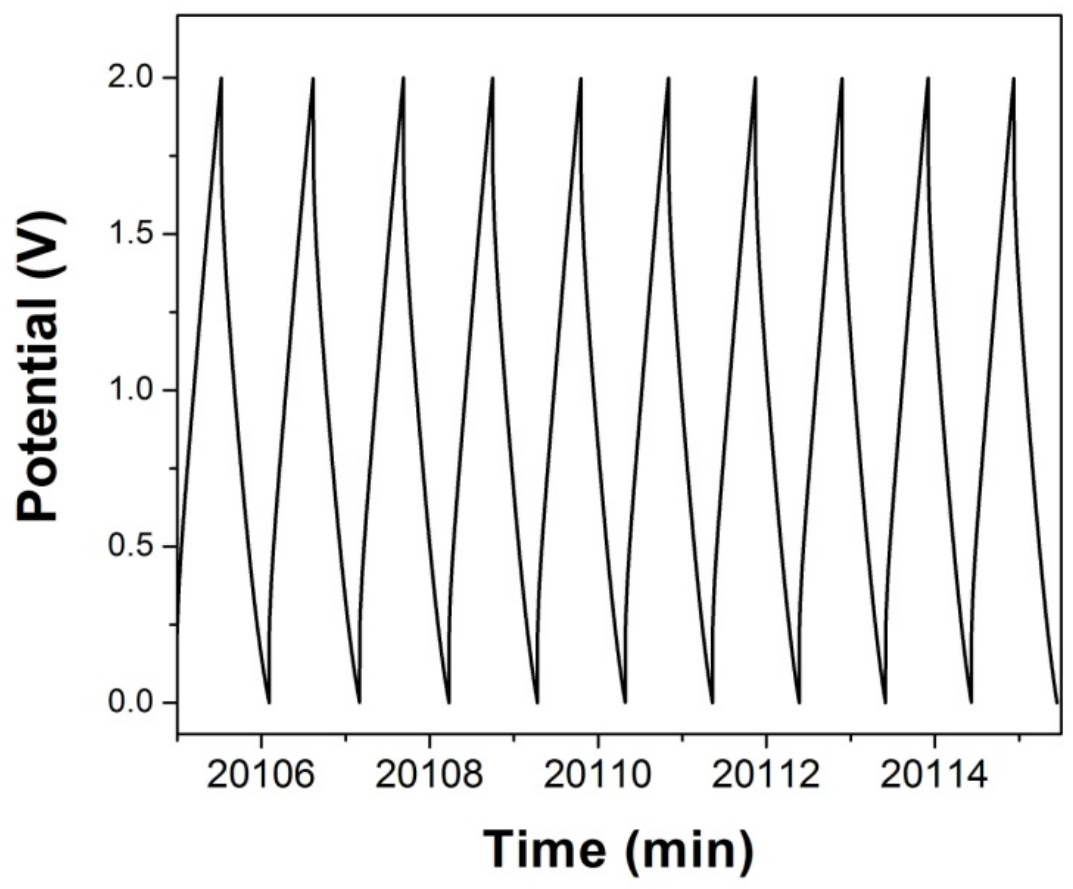

Fig. S4 Galvanostatic charge/discharge curves of the last 10 cycles out of 20,000 cycles at a current density of $2.0 \mathrm{~A} \mathrm{~g}^{-1}$ of the as-assembled ASCs. 


\section{Reference}

1. M. S. Hong, S. H. Lee and S. W. Kim, Electrochem. Solid. St., 2002, 5, A227-A230.

2. T. Brousse, M. Toupin and D. Belanger, J. Electrochem. Soc., 2004, 151, A614-A622.

3. T. Cottineau, M. Toupin, T. Delahaye, T. Brousse and D. Belanger, Appl. Phys. a-Mater., 2006, 82, 599-606.

4. T. Brousse, P. L. Taberna, O. Crosnier, R. Dugas, P. Guillemet, Y. Scudeller, Y. Zhou, F. Favier, D. Belanger and P. Simon, J. Power. Sources, 2007, 173, 633-641.

5. Q. T. Qu, L. Li, S. Tian, W. L. Guo, Y. P. Wu and R. Holze, J. Power Sources, 2010, 195, 2789-2794.

6. Q. T. Qu, Y. Shi, S. Tian, Y. H. Chen, Y. P. Wu and R. Holze, J. Power Sources, 2009, 194, $1222-$ 1225.

7. X. Zhang, P. Yu, H. T. Zhang, D. C. Zhang, X. Z. Sun and Y. W. Ma, Electrochim. Acta, 2013, 89, 523-529.

8. Y. T. Wang, A. H. Lu, H. L. Zhang and W. C. Li, J. Phys. Chem. C, 2011, 115, 5413-5421.

9. H. C. Gao, F. Xiao, C. B. Ching and H. W. Duan, ACS Appl. Mater. Inter., 2012, 4, 2801-2810.

10. Q. T. Qu, P. Zhang, B. Wang, Y. H. Chen, S. Tian, Y. P. Wu and R. Holze, J. Phys. Chem. C, 2009, 113, 14020-14027.

11. J. Cao, Y. Wang, Y. Zhou, J.-H. Ouyang, D. Jia and L. Guo, J. Electroanal. Chem., 2013, 689, 201206.

12. M. Yeager, W. X. Du, R. Si, D. Su, N. Marinkovic and X. W. Teng, J. Phys. Chem. C, 2012, 116, 20173-20181.

13. V. Khomenko, E. Raymundo-Pinero and F. Beguin, J. Power Sources, 2006, 153, 183-190.

14. V. Khomenko, E. Raymundo-Pinero, E. Frackowiak and F. Beguin, Appl. Phys. A-Mater., 2006, 82, 567-573.

15. Z. S. Wu, W. C. Ren, D. W. Wang, F. Li, B. L. Liu and H. M. Cheng, ACS Nano, 2010, 4, 5835-5842.

16. Z. B. Lei, J. T. Zhang and X. S. Zhao, J. Mater. Chem., 2012, 22, 153-160.

17. Y. L. Shao, H. Z. Wang, Q. H. Zhang and Y. G. Li, J. Mater. Chem. C, 2013, 1, 1245-1251.

18. Z. J. Fan, J. Yan, T. Wei, L. J. Zhi, G. Q. Ning, T. Y. Li and F. Wei, Adv. Funct. Mater., 2011, 21, 2366-2375. 